\title{
PENGARUH PENGGUNAAN METODE PEMBELAJARAN TERHADAP HASIL BELAJAR MATEMATIKA DITINJAU DARI SIKAP SISWA PADA PELAJARAN MATEMATIKA
}

(Eksperimen pada Sekolah Menengah Pertama Negeri di Kecamatan Cimanggis)

\section{Sita Husnul Khotimah}

Sekolah Tinggi Agama Islam ALHIKMAH Jakarta sita_kh81@yahoo.com

\section{Abstract}

The purpose of this study is to determine the effect of learning methods on students' mathematics learning outcomes, find out the influence of students' attitudes toward students' mathematics learning outcomes. Moreover, to know the influence of learning methods and students' attitudes together with the students' mathematics learning outcomes. Sample used from the affordable population were taken by 20 people as samples of instrument test and 64 people as research samples using proportional random sampling technique from all VII grade in state SMP 7 and state SMP 8 Depok West Java. Data collection is carried out by the technique of giving learning test result and by questionnaire dispersion. The data analysis consists of testing the research instrument through validity, reliability, difficulty index, and distinguishing strength. Then test the requirement analysis using normality test and homogeneity test. Hypothesis testing with 2 lane ANOVA test and Tukey test. Based on the result of hypotheses and data analisis, summed up some things as follows. 1) The students' mathematics learning outcomes that were taught using group work methods 
were higher than using conventional methods. 2) There is influence of interaction between learning method and student attitude on students' mathematics learning outcomes. 3) There is difference on the result of mathematics learning by group work method which is better than mathematics learning outcomes with conventional methods, on the group of students with positif attitudes. There is not difference on mathematics learning outcomes by group work methods or conventional methods on the group of students with negative attitudes.

Keywords: Learning methods, Student attitudes, Learning outcomes 


\section{Abstrak}

Tujuan dari Penelitian ini adalah untuk mengetahui pengaruh metode pembelajaran terhadap hasil belajar matematika siswa, mengetahui pengaruh sikap siswa terhadap hasil belajar matematika siswa. Selanjutnya untuk mengetahui pengaruh metode pembelajaran dan sikap siswa secara bersama-sama terhadap hasil belajar matematika siswa. Metode penelitian yang digunakan adalah eksperimen. Sampel yang digunakan dari populasi terjangkau diambil 20 orang sebagai sampel ujicoba instrumen dan 64 orang sebagai sampel penelitian menggunakan teknik proporsional random sampling dari seluruh kelas VII di SMP Negeri 7 dan SMP Negeri 8 Depok Jawa Barat. Pengumpulan data dilaksanakan dengan teknik pemberian tes hasil belajar dan dengan penyebaran angket. Analisis data terdiri dari pengujian instrumen penelitian dengan uji validitas, reliabilitas, indeks kesukaran, dan daya pembeda. Selanjutnya dilakukan uji persyaratan analisis dengan uji normalitas dan uji homogenitas. Pengujian hipotesis dengan uji ANOVA 2 Jalur dan Uji Tukey. Berdasarkan hasil hipotesis dan analisis data, disimpulkan beberapa hal sebagai berikut: 1) Hasil belajar matematika siswa yang diajar dengan menggunakan metode kerja kelompok lebih tinggi dari pada dengan menggunakan metode konvensional. 2) Terdapat pengaruh interaksi antara metode pembelajaran dan sikap siswa terhadap hasil belajar matematika siswa. 3) Ada perbedaan hasil belajar matematika dengan metode kerja kelompok lebih baik dari pada hasil belajar matematika dengan metode konvensional pada kelompok siswa yang bersikap positif. Tidak ada perbedaan hasil belajar matematika dengan metode kerja kelompok maupun metode konvensional pada kelompok siswa yang bersikap negatif

Kata Kunci: Metode pembelajaran, Sikap siswa, Hasil belajar 


\section{A. PENDAHULUAN}

$\mathrm{P}$ eningkatan mutu dan relevansi pendidikan merupakan salah satu program pembangunan nasional dan rencana strategis di bidang pendidikan nasional. Peningkatan mutu dan relevansi pendidikan nasional sangat erat kaitannya dengan pengembangan Sumber Daya Manusia (SDM). Selaras dengan kebijakan pembangunan nasional yang menekankan pada pengembangan SDM maka upaya peningkatan mutu pendidikan merupakan hal penting. Dalam upaya peningkatan mutu pendidikan tersebut, mutu guru merupakan komponen yang paling menentukan. Guru memegang peranan strategis dalam transformasi amanat kurikulum kepada siswa melalui proses pembelajaran.

Masalah pokok yang dihadapi oleh dunia pendidikan di Indonesia adalah rendahnya kualitas pendidikan pada setiap jenjang dan satuan pendidikan. Banyak faktor yang menyebabkan rendahnya kualitas pendidikan di Indonesia. Salah satunya adalah kurikulum yang selama ini selalu bersifat sentralistik, menafikan keragaman dan hanya berorientasi pada penguasaan materi pelajaran (ranah kognitif). Padahal Indonesia adalah Negara yang majemuk, kaya akan keragaman potensi sosial-budaya yang jika diakomodasikan dalam kurikulum akan menjadi kekuatan penting bagi upaya peningkatan kualitas pendidikan.

Penguasaan ilmu matematika mutlak dimiliki oleh setiap orang, mengingat matematika merupakan induk ilmu pengetahuan. Matematika saat ini belum menjadi pelajaran yang difavoritkan, bahkan mata pelajaran ini kerap dianggap momok bagi sebagian besar siswa. Tugas guru matematika menjadi ganda. Pertama, bagaimana materi ajar sampai kepada siswa sesuai dengan standar kurikulum. Kedua, bagaimana proses pembelajaran berlangsung dengan pelibatan siswa secara penuh, dalam artian proses pembelajaran yang berlangsung dapat berjalan dengan menyenangkan. Sebuah tantangan bagi guru matematika untuk senantiasa berpikir dan bertindak kreatif.

Masalah pada tahap pertama, yakni menyampaikan materi sesuai standar kurikulum saja masih menjadi masalah. 
Pembelajaran umum matematika yang dirumuskan oleh National Council of Teachers of Matematics atau NCTM (tahun 2000) menggariskan bahwa siswa harus mempelajari matematika melalui pemahaman bahan ajar dan aktif membangun pengetahuan baru dari pengalaman dan pengetahuan yang dimiliki sebelumnya.

Untuk mewujudkan hal itu, dirumuskan lima tujuan umum pembelajaran matematika, yaitu : (1) belajar untuk berkomunikasi (mathematical communication); (2) belajar untuk bernalar (mathematical reasoning); (3) belajar untuk memecahkan masalah (mathematical problem solving); (4) belajar untuk mengaitkan ide (mathematical connections); dan (5) pembentukan sikap positif terhadap matematika (positive attitudes toward mathematics). Semua itu lazim disebut mathematical power (daya matematika).

Proses pengembangan mathematical power merupakan sebuah proses yang kompleks. Dalam arti siswa belajar matematika tidak hanya bergantung pada "apa" yang diajarkan, tetapi juga bergantung pada "bagaimana" matematika itu diajarkan. Bila diamati pernyataan di atas bahwa siswa mempelajari matematika untuk mendapatkan ilmu atau materi matematika, untuk mendapatkan materi matematika tersebut maka guru menyampaikan melalui suatu metode pembelajaran yang tepat agar materi matematika dapat dipahami secara benar.

Proses pembelajaran yang dilakukan oleh guru matematika di dalam kelas sangat berpengaruh terhadap peningkatan sikap dan hasil belajar siswa. Selama ini hasil belajar siswa dalam mata pelajaran matematika dapat dikatakan selalu rendah jika dibanding dengan mata pelajaran lain. Salah satu faktor penyebabnya adalah kurangnya strategi yang digunakan oleh guru matematika, termasuk menggunakan berbagai metode pembelajaran yang sesuai dengan topikyang diajarkan. Pendekatan dengan tugas kelompokmerupakan salah satu pendekatan yang sangat penting dalam pembelajaran matematika dewasa ini, karena di samping sebagai tujuan umum pembelajaran matematika dapat juga menumbuhkembangkan sikap dan menghargai kemanfaatan matematika dalam penerapannya pada ilmu lain dan dalam kehidupan sehari-hari. 
Di samping hal-hal tersebut di atas, sikap siswa dalam menjalankan proses pembelajaran juga sudah selayaknya menjadi perhatian para pendidik. Sikap yang baik dan cenderung positif pada dasarnya memberikan dampak yang cukup signifikan apabila dilihat keterkaitannya dengan hasil belajar siswa. Matematika sebagai mata pelajaran yang konkret membutuhkan sebuah perhatian dan pemahaman akan konsep yang cukup dalam, sehingga tidak dapat dipungkiri bahwa apabila siswa tertarik atau bersikap positif terhadap mata pelajaran ini bukan tidak mungkin siswa tersebut mendapatkan hasil yang cukup memuaskan.

Dari sisi lain penguasaan materi (kompetensi) guru juga dapat mempengaruhi hasil belajar siswa, karena bila materi yang disampaikan tidak dikuasai oleh guru, maka siswa pun tidak akan memahamiapayang diajarkannya. MenurutUsman (1995:50) bahwa "penguasaan materi bagi guru merupakan hal sangat menentukan, khususnya dalam proses belajar mengajar yang melibatkan guru mata pelajaran." Begitu juga dengan profesionalisme guru memiliki hubungan terhadap hasil belajar siswa, maksudnya adalah bahwa guru yang profesional yang salah satu cirinya menguasai materi pembelajaran, sangat berperan dalam keberhasilan siswa sehingga tujuan yang ingin dicapai dapat terwujud.

Berdasarkan uraian di atas, menarik kiranya diadakan penelitian dan kajian lebih dalam mengenai pengaruh metode pengajaran terhadap hasil belajar matematika ditinjau dari sikap siswa.

\section{B. KAJIAN TEORITIK}

\section{Pengaruh metode pembelajaran terhadap hasil belajar matematika siswa.}

Dalam kegiatan belajar mengajar guru mampu menciptakan iklim belajar yang efektif. Jadi keberhasilan siswa dalam proses belajar mengajar sangat ditentukan oleh kemampuan guru dalam memilih strategi pembelajaran terutama metode kerja kelompok. 
Dengan pendekatan kerja kelompok dimungkinkan siswa dapat belajar secara bersama-sama atau adanya proses gotong royong dimana siswa yang pandai dapat menjelaskan materi yang sulit kepada siswa yang kurang pandai untuk memecahkan masalah dalam matematika guna mencapai hasil belajar yang optimal. Sedangkan dengan metode konvensional siswa tidak banyak berperan aktif karena semua proses belajar dikendalikan oleh guru, sehingga siswa hanya menerima materi pelajaran tanpa dapat melakukan interaksi dengan gurunya, kerena siswa tersebut harus belajar secara mandiri dan kemampuan siswa juga tidak dapat berkembang, hal ini sudah dapat diduga bahwa hasil yang diterima siswa akan minimal.

Dari uraian di atas, penulis dapat menginterprestasikan bahwa hasil belajar matematika dengan menggunakan metode kerja kelompok lebih baik dari pada hasil belajar matematika dengan menggunakan metode konvensional.

\section{Pengaruh sikap siswa terhadap hasil belajar matematika.}

Kegiatan belajar yang dilakukan oleh para siswa perlu adanya sebuah sikap positif dari dalam diri sendiri. Agar hasil belajar yang diinginkan tercapai maka sikap positif harus segera dikembangkan sejak dini. Siswa yang bersikap positif terhadap matematika, maka ia akan tertarik dengan pelajaran tersebut, ketertarikan siswa tersebut dapat dipengaruhi oleh berbagai cara misalnya ia mengetahui manfaat dari belajar matematika atau ia juga sangat tertarik dengan matematika karena berhubungan dengan kehidupan sehari-hari.

Siswa yang memiliki sikap positif dalam belajar matematika tentu saja memiliki hasil belajar matematika yang baik, sebaliknya siswa yang memiliki sikap negatif terhadap matematika maka akan memperoleh hasil belajar matematika yang rendah pula. Untuk itu perlu dukungan dari tenaga pendidik (guru) untuk memberikan minat kepada peserta didiknya agar dapat menghasilkan hasil belajar matematika yang maksimal. Dengan demikian dapat disimpulkan bahwa 
hasil belajar matematika sangat ditentukan dari positif atau negatif sikap siswa terhadap matematika.

\section{Pengaruh interaksi metode pembelajaran dan sikap siswa terhadap hasil belajar matematika.}

Hasil belajar siswa dapat dipengaruhi oleh berbagai faktor, baik internal maupun eksternal. Metode kerja kelompok sebagai faktor eksternal, akan memberikan pengaruh terhadap hasil belajar matematika begitu pula dengan sikap siswa yang positif terhadap matematika memberikan hasil belajar yang lebih baik.

Bila dibandingkan dengan proses belajar mengajar dengan menggunakan metode konvensional serta sikap siswa yang negatif, maka hasil belajar yang dicapai akan buruk. Oleh karena itu guru yang memiliki peran yang sangat penting dalam pembelajaran sangat dianjurkan untuk memberikan strategi pembelajaran yang tepat dan merubah persepsi siswa menjadi sikap yang positif terhadap matematika.

Dari uraian di atas, penulis dapat menginterprestasikan bahwa terdapat interaksi antara penggunaan metode mengajar dengan sikap siswa terhadap matematika dalam mempengaruhi hasil belajar matematika.

\section{METODE PENELITIAN}

\section{Jenis Penelitian}

Pada penelitian ini, penulis menggunakan metode eksperimen. Penelitian ini akan menguji pengaruh metode pembelajaran dan sikap siswa terhadap hasil belajar matematika. Variabel bebas dalam penelitian ini adalah metode pembelajaran $\left(\mathrm{X}_{1}\right)$ dan sikap siswa $\left(\mathrm{X}_{2}\right)$. Metode pembelajaran sebagai variabel perlakuan dan sikap siswa sebagai variabel atribut. Sedangkan variabel terikatnya adalah hasil belajar matematika (Y). 
Adapun desain eksperimen yang digunakan dalam penelitian ini adalah factorial design.

\begin{tabular}{|c|c|c|c|}
\hline Sembelajaran & $\begin{array}{r}\text { Metode } \\
\text { Metode Kerja } \\
\text { Kelompok }\left(\mathrm{A}_{1}\right)\end{array}$ & $\begin{array}{c}\text { Metode } \\
\text { Konvensional }\left(\mathrm{A}_{2}\right)\end{array}$ & Jumlah \\
\hline Positif $\left(\mathrm{B}_{1}\right)$ & $\mathrm{A}_{1} \mathrm{~B}_{1}$ & $\mathrm{~A}_{2} \mathrm{~B}_{1}$ & $\mathrm{~B}_{1}$ \\
\hline Negatif $\left(\mathrm{B}_{2}\right)$ & $\mathrm{A}_{1} \mathrm{~B}_{2}$ & $\mathrm{~A}_{2} \mathrm{~B}_{2}$ & $\mathrm{~B}_{2}$ \\
\hline Jumlah & $\mathrm{A}_{1}$ & $\mathrm{~A}_{2}$ & \\
\hline
\end{tabular}

Tabel 1 : Disain eksperimen

Keterangan :

$\mathrm{A}=$ Metode pembelajaran matematika

$\mathrm{A}_{1}=$ Siswa yang diberi metode kerja kelompok

$A_{2}=$ Siswa yang diberi metode konvensional

$\mathrm{B}=$ Sikap belajar matematika

$\mathrm{B}_{1}=$ Siswa yang memiliki sikap positif

$\mathrm{B}_{2}=$ Siswa yang memiliki sikap negatif

$\mathrm{A}_{1} \mathrm{~B}_{1}=$ Siswa yang diberi metode kerja kelompok dan memiliki sikap positif

$\mathrm{A}_{2} \mathrm{~B}_{1}=$ Siswa yang diberi metode konvensional dan memiliki sikap positif

$\mathrm{A}_{1} \mathrm{~B}_{2}=$ Siswa yang diberi metode kerja kelompok dan memiliki sikap negatif

$\mathrm{A}_{2} \mathrm{~B}_{2}=$ Siswa yang diberi metode konvensional dan memiliki sikap negatif

\section{Tempat dan Waktu Penelitian}

Penelitian ini dilakukan di Sekolah Menengah Pertama Negeri 7 dan Sekolah Menengah Pertama Negeri 8 Kecamatan Cimanggis Depok. Penelitian dilakukan dalam dua tahap, tahap pertama dilakukan penelitian pendahuluan yaitu mengumpulkan data terkait dengan jumlah populasi dan jumlah sampel yang akan dijadikan obyek penelitian. Tahap kedua melakukan uji coba instrumen dan ditindaklanjuti dengan penelitian untuk pengambilan data yang dilaksanakan pada bulan Mei-Juni tahun 2012. 


\section{Populasi dan Teknik Pengambilan Sampe}

a. Populasi Penelitian

Populasi dalam penelitian ini adalah seluruh siswa Sekolah Menengah Pertama Negeri di Wilayah Kecamatan Cimanggis Depok, pada semester genap tahun pelajaran 2011-2012.

b. Sampel Penelitian

Sampel penelitian ini seluruhnya diambil dari populasi siswa kelas VII Sekolah Menengah Pertama Negeri 7 dan Sekolah Menengah Pertama Negeri 8 di Kecamatan Cimanggis Depok. Pilihan terhadap sampel siswa dari populasi tersebut dilakukan dengan teknik simple random sampling.

c. Tehnik Pengambilan Sampel

Menurut Suharsimi Arikunto, pengertian sampel adalah wakil populasi yang diteliti, dimaksudkan untuk menggeneralisasikan hasil penelitian sampel (Suharsimi Arikunto, 2002: 109).

Ada beberapa rumus yang dapat digunakan oleh peneliti untuk menentukan jumlah anggota sampel. Sebagai ancer-ancer, jika peneliti mempunyai beberapa ratus subjek dalam populasi, mereka dapat menentukan kurang lebih 25 - 30\% dari jumlah tersebut. (Suharsimi Arikunto, 2009 : 95).

Dalam penelitian ini peneliti mengambil sampel 64 orang, dengan teknik yang digunakan dalam pengambilan sampel adalah teknik proporsional random sampling.

d. Instrumen Penelitian

Instrumen yang digunakan sebagai alat penelitian disusun berdasarkan kisi-kisi. Penyusunan kisi-kisi berdasarkan indikator yang telah dibahas. Pengukuran hasil belajar matematika dan sikap siswa ditunjukkan 


\section{sebagai berikut :}

\section{Kisi- kisi instrument Hasil Belajar Matematika}

\section{Tabel 2. Kisi-kisi Instrumen Hasil Belajar Matematika}

\begin{tabular}{|c|c|c|c|c|c|}
\hline $\begin{array}{l}\text { Kompetensi } \\
\text { Dasar }\end{array}$ & Materi & Indikator & No Soal & \begin{tabular}{|l|} 
Jmlh \\
Soal
\end{tabular} & Ability \\
\hline \multirow{3}{*}{$\begin{array}{l}\text { Mengidentifikasi } \\
\text { sifat-sifat persegi } \\
\text { panjang, persegi, } \\
\text { trapesium, } \\
\text { jajargenjang, } \\
\text { belah ketupat dan } \\
\text { layang-layang }\end{array}$} & \multirow{3}{*}{$\begin{array}{l}\text { Sifat-sifat } \\
\text { persegi } \\
\text { panjang, } \\
\text { persegi, } \\
\text { trapesium, } \\
\text { jajargenjang, } \\
\text { belah ketupat } \\
\text { dan layang- } \\
\text { layang }\end{array}$} & $\begin{array}{l}\text { 1. Menentukan banyaknya } \\
\text { sumbu simetri dan simetri } \\
\text { putar }\end{array}$ & 1,7 & 2 & $C_{1}$ \\
\hline & & $\begin{array}{l}\text { 2. Menentukan sifat-sifat } \\
\text { bangun segi empat }\end{array}$ & $\begin{array}{l}2,12,16 \\
21,25\end{array}$ & 5 & $C_{1}, C_{2}$ \\
\hline & & $\begin{array}{l}\text { 3. Menentukan besar sudut } \\
\text { pada bangun segi empat }\end{array}$ & 5,24 & 2 & $C_{2}, C_{3}$ \\
\hline \multirow{5}{*}{$\begin{array}{l}\text { Menghitung } \\
\text { keliling dan luas } \\
\text { bangun segi } \\
\text { empat serta } \\
\text { menggunakannya } \\
\text { dalam pemecahan } \\
\text { masalah }\end{array}$} & \multirow{5}{*}{$\begin{array}{l}\text { Keliling dan } \\
\text { luas bangun } \\
\text { segi empat }\end{array}$} & $\begin{array}{l}\text { 1. Menentukan keliling } \\
\text { bangun segi empat }\end{array}$ & $6,11,26$ & 3 & $C_{2}$ \\
\hline & & $\begin{array}{l}\text { 2. Menentukan luas bangun } \\
\text { segi empat }\end{array}$ & $\begin{array}{l}3,9,13, \\
14,19 \\
20,23 \\
27\end{array}$ & 8 & $C_{3}, C_{4}$ \\
\hline & & $\begin{array}{l}\text { 3. Menentukan salah satu } \\
\text { unsur jika diketahui luasnya }\end{array}$ & $\begin{array}{l}8,10,15 \\
17,22\end{array}$ & 5 & $\mathrm{C}_{3}, \mathrm{C}_{4}$ \\
\hline & & $\begin{array}{l}\text { 4. Menentukan unsur yang } \\
\text { belum diketahui pada } \\
\text { bangun segi empat }\end{array}$ & 4,18 & 2 & $\mathrm{C}_{3}, \mathrm{C}_{4}$ \\
\hline & & $\begin{array}{l}\text { 5. Menyelesaikan soal cerita } \\
\text { dengan konsep keliling dan } \\
\text { luas bangun segi empat }\end{array}$ & $28,29,30$ & 3 & $\mathrm{C}_{4}, \mathrm{C}_{5}$ \\
\hline
\end{tabular}

\section{Kisi-kisi instrument Sikap siswa}

Tabel 3.Kisi-kisi pengukuran sikap siswa

\begin{tabular}{|c|c|c|c|}
\hline \multirow{2}{*}{ Indikator Sikap } & \multicolumn{3}{|c|}{ Dimensi } \\
\cline { 2 - 4 } & Kognisi & Afeksi & Psikomotor \\
\hline \multirow{2}{*}{ Sikap Positif' } & $1,3,10,11,16,17$ & $5,7,13,20,21,24$ & $14,22,29$ \\
& & & \\
Sikap Negatif & $6,9,15,15,28,30$ & $\begin{array}{c}2,4,8,25,27,31,32, \\
\text { 33, 35 }\end{array}$ & $12,19,23,26,34$ \\
\hline
\end{tabular}




\section{Teknik Analisis Data}

1. Teknik Analisis Data Deskriptif

Setelah data terkumpul yang diperoleh melalui instrumen yang dipilih, langkah berikutnya adalah mengolah dan menganalisis data untuk menjawab pertanyaan penelitian, atau menguji hipotesis dengan menggunakan SPSS 16.

2. Teknik Analisis Persyaratan Data

a. Uji Normalitas

Sebelum dilakukan pengujian hipotesis, berdasarkan data-data yang terkumpul dari hasil penelitian ini, terhadap data-data tersebut terlebih dahulu dilakukan uji normalitas. Uji normalitas ini dilakukan dengan menggunakan SPSS 16 yaitu dengan Kolmogorov Smirnov dengan taraf signifikan $\alpha=0,05$ dengan jumlah responden sebanyak 64 orang dengan hipotesis pengujian normalitas sebagai berikut:

$\mathrm{H}_{\mathrm{o}}$ : Data berdistrubsi normal

$\mathrm{H}_{\mathrm{a}}$ : Data berdistribusi tidak normal

Kriteria pengujian dengan menggunakan nilai probabilitas (Sig)

Terima $\mathrm{H}_{\mathrm{o}}$ : Jika nilai probabilitas $>0,05$ yang berarti data berdistribusi normal

Tolak $\mathrm{H}_{\mathrm{o}}$ : Jika nilai probabilitas $<0,05$ yang berarti data tidak berdistribusi normal

b. Uji Homogenitas

Setelah melakukan uji normalitas memberikan indikasi data hasil penelitian berdistribusi normal, maka selanjutnya akan dilakukan uji homogenitas dari sample penelitian dengan menggunakan SPSS 16. Kriteria pengujian dengan menggunakan nilai probabilitas (Sig) 
Terima $\mathrm{H}_{\mathrm{o}}$ : Jika nilai probabilitas $>0,05$ yang berarti data homogen

Tolak $\mathrm{H}_{\mathrm{o}}$ : Jika nilai probabilitas $<0,05$ yang berarti data tidak homogen

3. Teknik Uji Hipotesis Penelitian

Analisis uji hipotesis penelitian menggunakan anava dua jalan. Analisis Varians (Anava) dua jalan merupakan teknik analisis data penelitiandengan menggunakan SPSS 16.

Kriteria pengujian dengan menggunakan nilai probabilitas (Sig)

Terima $\mathrm{H}_{\mathrm{o}}$ : Jika nilai sig> 0,05 yang berarti ada pengaruh

Tolak $\mathrm{H}_{\mathrm{o}}$ : Jika nilai sig $<0,05$ yang berarti tidak ada pengaruh

Uji Lanjut

Uji lanjut dilakukan untuk mengetahui pengaruh perbedaan masing-masing kelompok dengan menggunakan Uji Tukey (karena data perkelompok sama), jika dalam pengujian hipotesis diperoleh interaksi yang signifikan.

\section{HASIL PENELITIAN DAN PEMBAHASAN}

\section{Deskripsi Data Penelitian}

Dalam uraian berikut ini dideskripsikan tentang hasil belajar matematika siswa pada mata pelajaran matematika di SMP Negeri 7 dan SMP Negeri 8 Depok dengan rincian kelompok data sebagai berikut : (1) data hasil belajar matematika siswa yang diberi metode kerja kelompok (2) data hasil belajar matematika siswa yang diberi metode konvensional, (3) data hasil belajar matematika siswa dengan sikap positif, (4) data hasil belajar matematika siswa dengan sikap remdah, (5) data hasil belajar matematika yang diberi metode kerja kelompok dengan sikap positif (6), data hasil belajar matematika siswa 
yang diberi metode konvensional dengan sikap positif, (7) data hasil belajar matematika siswa yang diberi metode kerja kelompok dengan sikap negatif, (8) data hasil belajar matematika siswa yang diberi metode konvensional dengan sikap negatif.

Tabel 4. Rangkuman Data Deskriptif

\begin{tabular}{|c|c|c|c|}
\hline \multirow{2}{*}{$\begin{array}{c}\text { Metode Pembelajaran } \\
\text { Sikap Siswa }\end{array}$} & \multicolumn{2}{|c|}{ Metode Pembelajaran (A) } & \multirow[b]{2}{*}{ Total } \\
\hline & $\begin{array}{c}\text { Kerja Kelompok } \\
\left(\mathbf{A}_{1}\right)\end{array}$ & $\begin{array}{c}\text { Konvensional } \\
\left(\mathbf{A}_{2}\right)\end{array}$ & \\
\hline \multirow{3}{*}{$\begin{array}{l}\text { Sikap Positif } \\
\left(B_{1}\right)\end{array}$} & $\mathrm{n}=16$ & $\mathrm{n}=16$ & $\mathrm{n}=32$ \\
\hline & $\bar{X}=20.81$ & $\bar{X}=15.38$ & $\bar{X}=18.09$ \\
\hline & $s=1.870$ & $s=3.594$ & $s=3.946$ \\
\hline \multirow{3}{*}{$\begin{array}{l}\text { Sikap Negatif } \\
\left(B_{2}\right)\end{array}$} & $\mathrm{n}=16$ & $\mathrm{n}=16$ & $\mathrm{n}=32$ \\
\hline & $\bar{X}=14.94$ & $\bar{X}=14.50$ & $\bar{X}=14.72$ \\
\hline & $s=3.785$ & $\mathrm{~s}=2.875$ & $\mathrm{~s}=3.314$ \\
\hline \multirow{3}{*}{ Total } & $\mathrm{n}=32$ & $\mathrm{n}=32$ & $\mathrm{n}=64$ \\
\hline & $\bar{X}=17.88$ & $\bar{X}=14.94$ & $\bar{X}=17.49$ \\
\hline & $s=4.187$ & $\mathrm{~s}=3.232$ & $s=3.031$ \\
\hline
\end{tabular}

Demikianlah deskripsi data untuk kedelapan kelompok yang telah disebutkan di atas. Selanjutnya akan dipaparkan hasil pengujian persyaratan analisis varians dan pengujian hipotesis penelitian.

\section{Pengujian Persyaratan Analisis}

Pengujian hipotesis pada penelitian ini dilakukan dengan menggunakan analisis varians (ANAVA) dua jalan. Oleh karena itu sebelum dilakukan analisis lebih lanjut terlebih dahulu dilakukan uji persyaratan ANAVA yang meliputi uji normalitas dan homogenitas.

a. Uji Normalitas

Uji normalitas untuk semua kelompok data dilakukan 
dengan uji Lilliefors pada taraf signifikansi $0,05=\alpha$ dengan bantuan program SPSS 16 . Hasil perhitungannya disajikan dalam tabel berikut:

Tabel 5. Perhitungan Normalitas Data dengan SPSS

\begin{tabular}{|c|c|c|c|c|c|c|c|c|c|}
\hline \multicolumn{10}{|c|}{ One-Sample Kolmogorov-Smirnov Test } \\
\hline & & MKK & MK & SP & SN & MKKSP & MKKSN & MKSP & MKSN \\
\hline $\mathrm{N}$ & & 32 & 32 & 32 & 32 & 16 & 16 & 16 & 16 \\
\hline \multirow{2}{*}{$\begin{array}{l}\text { Normal } \\
\text { Parameters }\end{array}$} & Mean & 17.88 & 14.94 & 18.09 & 14.72 & 20.81 & 14.94 & 15.38 & 14.50 \\
\hline & $\begin{array}{l}\text { Std. } \\
\text { Deviation } \\
\end{array}$ & 4.187 & 3.232 & 3.946 & 3.314 & 1.870 & 3.785 & 3.594 & 2.875 \\
\hline \multirow{3}{*}{$\begin{array}{l}\text { Most } \\
\text { Extreme } \\
\text { Differences }\end{array}$} & Absolute & .137 & .100 & .147 & .096 & .148 & .132 & .142 & .120 \\
\hline & Positive & .079 & .100 & .076 & .091 & .148 & .091 & .108 & .120 \\
\hline & Negative & -.137 & -.078 & -.147 & -.096 & -.129 & -.132 & -.142 & -.069 \\
\hline \multicolumn{2}{|c|}{ Kolmogorov-Smirnov Z } & .776 & .563 & .830 & .545 & .590 & .526 & .570 & .481 \\
\hline \multicolumn{2}{|c|}{ Asymp. Sig. (2-tailed) } & .584 & .909 & .496 & .928 & .877 & .945 & .902 & .975 \\
\hline \multicolumn{2}{|c|}{$\begin{array}{l}\text { a. Test distribution is } \\
\text { Normal. }\end{array}$} & & & & & & & & \\
\hline
\end{tabular}

Hipotesis statistik:

$\mathrm{H}_{0}$ : Data berasal dari populasi yang berdistribusi normal

$\mathrm{H}_{1}$ : Data tidak berasal dari populasi yang berdistribusi normal

Kriteria pengujian:

Terima Ho jika Sig. (2-tailed) $>0,05=\alpha$.

Tolak Ho jika Sig. (2-tailed) $<0,05=\alpha$.

Dengan demikian dapat disimpulkan bahwa sampel penelitian ini berasal dari populasi yang berdistribusi normal.

b. Uji Homogenitas Antara kelompok $A_{1} B_{1}, A_{2} B_{1}, A_{1} B_{2}$, dan $\mathrm{A}_{2} \mathrm{~B}_{2}$

Uji homogenitas varians pada empat kelompok sel rancangan eksperimen yang dimaksud adalah uji homogenitas data skor hasil belajar siswa antara kelompok siswa yang memiliki sikap positif yang diberi metode pembelajaran kerja kelompok $\left(\mathrm{A}_{1} \mathrm{~B}_{1}\right)$, siswa memiliki sikap 
positif yang diberi metode pembelajaran konvensional $\left(\mathrm{A}_{2} \mathrm{~B}_{1}\right)$, siswa memiliki sikap negatif yang diberi metode pembelajaran kerja kelompok $\left(A_{1} B_{2}\right)$, siswa memiliki sikap negatif yang diberi metode pembelajaran konvensional $\left(\mathrm{A}_{2} \mathrm{~B}_{2}\right)$.

Untuk menguji homogenitas varians pada empat kelompok sel rancangan eksperimen dilakukan dengan bantuan program SPSS 16. Hasil perhitungannya dapat dilihat pada tabel berikut.

Tabel 6. Perhitungan Homogenitas Data Penelitian dengan SPSS

Levene's Test of Equality of Error Variances ${ }^{\text {a }}$

\begin{tabular}{|c|c|c|c|}
\hline \multicolumn{4}{|c|}{ Dependent Variable: HASIL BELAJAR } \\
\hline $\mathrm{F}$ & df1 & $\mathrm{df2}$ & Sig. \\
\hline 2.198 & 3 & 60 & .098 \\
\hline
\end{tabular}

Tests the null hypothesis that the error variance of the dependent variable is equal across groups.

a. Design: Intercept + METODE + SIKAP + METODE * SIKAP

Berdasarkan data yang terlihat pada tabel, diperoleh nilai Sig. $=0,098$. Karena Sig. $>0,05=\alpha$, maka Ho diterima. Dengan kata lain, data dari keempat kelompok sampel penelitian berasal dari populasi yang homogen atau memiliki varians yang homogen.

\section{Pengujian Hipotesis Penelitian}

Hasil pengujian hipotesis penelitian tersebut di atas ditafsirkan lebih lanjut sebagai berikut:

a. Pembahasan Hipotesis Pertama

Hipotesis penelitian yang mengatakan adanya perbedaan hasil belajar siswa yang diberi metode pembelajaran kerja kelompok dengan siswa yang diberi metode pembelajaran konvensional diterima. Hal ini berarti pemberian perlakuan dengan menggunakan metode pembelajaran, khususnya kerja kelompok lebih unggul dari pemberian perlakuan dengan metode pembelajaran 
konvensional pada saat kegiatan belajar mengajar.

Secara keseluruhan untuk pengukuran hasil belajar siswa yang mendapat metode pembelajaran kerja kelompok dan siswa yang mendapat metode pembelajaran konvensional memberikan hasil yang berbeda.

b. Pembahasan Hipotesis Kedua

Penelitian menemukan adanya interaksi antara metode pembelajaran dengan sikap siswa dalam pengaruhnya terhadap pencapaian hasil belajar siswa. Hal ini menunjukkan bahwa bukan hanya model, pendekatan, metode atau teknik pembelajaran saja yang perlu diperhatikan guru melainkan faktor-faktor psikologis siswa juga perlu mendapat perhatikan. Salah satu faktor tersebut adalah faktor sikap siswa.

Sikap siswa tentunya dipengaruhi oleh berbagi faktor, baik faktor dari dalam diri siswa itu sendiri maupun faktor luar seperti faktor kemampuan guru mengajar, faktor kemampuan guru dalam melakukan pendekatan dengan siswa serta faktor lainnya.

Jadi secara keseluruhan, baik metode pembelajaran maupun sikap siswa mempengaruhi pencapaian hasil belajar matematika siswa.

c. Pembahasan Hipotesis Ketiga

Pada kelompok siswa yang memiliki sikap positif, tidak ada perbedaan yang signifikan antara hasil belajar matematika siswa yang diajar dengan metode kerja kelompok dan metode konvensional. Hal ini ditunjukkan pula pada rata-rata skor hasil belajar matematika yang diajar dengan menggunakan metode kerja kelompok = 18,25 hampir sama dengan yang diajar dengan metode konvensional $=18,19$.

Dengan demikian artinya, untuk mereka yang memiliki sikap positif, sama efektifnya dalam pembelajaran 
matematika, antara yang diajar dengan menggunakan metode kerja kelompok maupun dengan metode konvensional.

\section{Hasil Uji Lanjut}

Pada kelompok siswa yang memiliki sikap negatif, tidak terdapat perbedaan yang signifikan antara hasil belajar matematika siswa yang diajar dengan dengan metode kerja kelompok dan metode konvensional. Artinya, untuk mereka yang memiliki sikap negatif, pembelajaran matematika dengan menggunakan metode kerja kelompok tidak lebih efektif dari pada metode konvensional.

\section{E. KESIMPULAN}

Berdasarkan penelitian di atas, maka kesimpulannya adalah:

1. Terdapat pengaruh yang signifikanmetode pembelajaran terhadap hasil belajar matematika siswa. Hal ini berdasarkan pada hasil analisis data yang diperoleh nilai $\mathrm{F}_{\text {hitung }}=14,157$ dan sig = 0,000. Nilai sig lebih kecil dari 0,05.

2. Terdapat pengaruh yang signifikansikap siswa terhadap hasil belajar matematika. Hal ini berdasarkan pada hasil analisis data yang diperoleh nilaiF ${ }_{\text {hitung }}=18,688 \mathrm{dan} \operatorname{sig}=0,000$. Nilai sig lebih kecil dari 0,05.

3. Terdapatpengaruh yang signifikaninteraksi metode pembelajaran dan sikap siswa dengan hasil belajar matematika. Hal ini berdasarkan pada hasil analisis data yang diperoleh $\mathrm{F}_{\text {hitung }}=10,254$ dan sig $=0,002$. Nilai sig lebih kecil dari 0,05. Maka diperlukan uji lanjut dengan hasil :

a. Ada perbedaan hasil belajar matematika dengan metode kerja kelompok lebih baik dari pada hasil belajar matematika dengan metode konvensional pada kelompok siswa yang bersikap positif, dengan sig 0,000 0,05.

b. Tidak ada perbedaan hasil belajar matematika dengan metode kerja kelompok maupun metode konvensional pada kelompok siswa yang bersikap negatif, dengan sig $0,979>0,05$ dan sig $0,858>0,05$. 


\section{DAFTAR PUSTAKA}

Agung, I Gusti Ngurah, Manajemen Penulisan Skripsi, Tesis, dan Desertasi, Jakarta: PT. Raja Grafindo Persada, 2004.

Gulo, Strategi Belajar-Mengajar, Jakarta: Gramedia widiasarana Indonesia, 2002.

Kardi, Suparman., Mohamad Nur, Pengantar pada Pengajaran dan Pengelolaan Kelas. Surabaya: University Press, 2000.

Cunayah, Cucun, Ringkasan dan Bank Soal Matematika, Bandung: Yrama Widya. 2006.

Djamarah, Syaiful Bahri, Psikologi Belajar, Jakarta: Rineka Cipta, 2002.

Hartono, SPSS 16, Analisis Data Statistika dan Penelitian, Yogyakarta: Pustaka Pelajar, 2008.

Kurniawan, Fokus Matematika Untuk SMP dan MTs, Jakarta: Erlangga, 2003.

Setyaningtyas, Yualind, Buku Sakti Matematika SMP, Yogyakarta: Kendi Mas Media, 2009.

Jalaludin, Jurnal Pendidikan, Kreativitas Guru Pacu Motivasi Belajar Siswa. Kamus Kimia Departemen Pendidikan Nasional, Balai Pustaka, 2007.

Shaleh, Abdul Rahman, Psikologi Suatu Pengantar dalam Perspektif Islam, Jakarta: Kencana, 2004.

Slameto, Belajar dan Faktor-faktor yang Mempengaruhinya. Jakarta: Rineka Cipta. 2003.

Sudjana, Nana, Penilaian Hasil Proses Belajar Mengajar, Bandung: PT. Remaja Rosdakarya, 2004.

Sudijono, Anas, Pengantar Evaluasi Pendidikan, Jakarta: Grafindo Persada, T.T. 
Sugiyono, Metode Penelitian Pendidikan, Bandung: Alfabeta, 2008.

Sugiyono, Metode Penelitian Bisnis, Bandung: Alfabeta, 2009.

Sukino dan Wilson Simangunsong. Matematika Untuk SMP Kelas VII. Jakarta: Erlangga. 2004.

Syah, Muhibbin, Psikologi Pendidikan dengan Pendekatan Baru, Bandung: Remaja Rosda Karya, 2005.

Statistika untuk Penelitian, Bandung: Alfabeta, 2006. 